Operation, August 1, 1946. An $8 \mathrm{~mm}$. recession of the right superior oblique was performed undèr local anaesthesia after temporary division of the superior rectus. This, of course, implies a movement of the oblique insertion forwards and inwards. After the operation it was decided that the inward movement was slightly greater and the forward movement less than the ideal. The result was reasonably good, however, the patient obtaining single binocular vision without prisms everywhere except to the left, where the divergence prevents it. Synoptophore readings on September 7, 1946, were as follows :-

$$
\begin{aligned}
& \text { Straight ahead }=0^{\circ} \mathrm{L} / \mathrm{R} 2^{\triangle} \\
& 20^{\circ} \text { to left }=-10^{\circ} \mathrm{L} / \mathrm{R} 9^{\Delta} \\
& 20^{\circ} \text { to right } .=0^{\circ} \mathrm{R} / \mathrm{L} 3^{\triangle} \\
& \text { REFERENCES }
\end{aligned}
$$

\section{REFERENCES}

1. BARRIÉRE.-Ann.d Ocul. 1932.

2. BORLEY and RENAUD.-U.S.N. Med. Bull., Vol. XLV, p.755. 1945.

3. Dunnington.-Trans. Amer. Ophthal. Soc., Vol. XXVII. p. 277.1929.

4. FriedenWald.-Amer. Arch. Ophthal., Vol. XV, p. 283.1936.

5. Gibson.-Amer. Jl. Ophthal., Vol. XXV, p. 565.1941.

6. GIFFORD.-Amer. Jl. Ophthal., Vol. XXV, p. 761. 1941.

7. Amer. Jl. Ophthal., Vol. XXVIII, p. 882. 1942.

8. Guibor.-Amer. Jl. Ophthal., Vol. XXVII, p. 254. 1944.

9. Hess.-Zeitschr. f. Augenheilk., Vol. XXXV, p. 201.1916.

10. Hughes.-Amer. Jl. Ophthal., Vol. XXVII, p. 1123. 1944.

11. HumMelsheim.-Ophthal. Ges. Heidelberg, p. 248.1907 .

12. JACKSON and O'Rourke.-Amer. Arch. Ophthal., Vol. II, p. 756.1929.

13. JACKSON.-Ophthal. Rev., Vol. LXI, p. 22. 1903.

14. Lancaster.-Jl. Amer. Med. Assoc. Sect. Ophthal., p. 78. 1939.

15. Peter.-Trans. Amer. Ophthal Soc., Vol. XXXI, p. 232. 1933.

16. Terrien.-Chirurgie de l'oeil, Paris, p. 523.1927.

17. WAGMAN.-Amer. Jl. Ophthal., Vol. XXVIII, p. 1226. 1945.

18. Wegner.-Klin. Monats. f. Augenheilk, Vol. C, p. 20.1938.

19. Wheeler.-Amer. Jl. Ophthal., Vol. XViII, p. 1. 1935.

20. White.-Amer. Jl. Ophthal., Vol. XXVI, p. 587.1943.

\title{
INFLAMMATORY JUGULAR PHLEBOSTENOSIS AS THE CAUSE OF GLAUCOMA EXOGENICUM*
}

\author{
BY \\ OtTo MEYER \\ NEW YORK CITY
}

THE term "glaucoma exogenicum" is introduced to differentiate this type of glaucoma with extra-ocular cause from " glaucoma endogenicum " that has an intra-ocular cause. Both types of glaucoma are secondary in nature.

Just as retinitis albuminurica has its cause outside of the eye, exogenic glaucoma has an extra-ocular cause.

* Received for publication, July 10, 1946. 
The cause of exogenic glaucoma was traced clinically by the author to a jugular phlebostenosis due to proliferative endophlebitis. It is desirable that pathologists examine the jugular veins of patients who die with exogenic glaucoma.

The author stressed in two papers the importance of inflammatory phlebostenosis of the jugular veins as the cause of the so-called "primary" glaucoma.

It is important to have a clear conception of the role which the internal jugular vein plays in the drainage of venous blood from the head region.

The bulk of the blood entering the head is drained off by the internal jugular veins on each side of the neck. A relatively small amount of venous blood passes through the external jugular veins. A very small portion returns by way of the suboccipital plexus into vertebral and deep cervical veins, and from there into the innominate vein.

The factors which promote the circulation in the veins are muscular contractions, gravity for the venous circulation above the level of the heart, suction exerted upon the heart and larger thoracic veins during expiration, and action of the right heart.

Haemodynamically it is a fundamental law of the circulation that the blood flows always from a point of higher pressure to a point of lower pressure. The point of zero pressure, i.e., where negative and positive pressures just balance one another, is in case of the upper part of the body in the jugular vein at the root of the neck. Below this point the pressure is negative. For this reason there is supposed to be danger, should a vein be nicked in this region during an operation, of air being sucked in and carried to the heart. The negative pressure varies between minus 35 and minus $80 \mathrm{~mm}$. of water at the right auricle.

The jugular vein has no valves and only two coats. The media is entirely lacking.

The negative pressure at the right auricle is an important factor for the drainage of the venous blood from the head area. Any resistance to the free flow of venous blood between the head area and the right auricle must increase the venous pressure in all distal veins in the head area. Haemodynamically any resistance to the flow of the blood influences the slope of pressure which is a deciding factor for a free flow of blood. The greater the slope of pressure, the better is the circulation.

A normal lumen of the endothelium of the internal jugular vein is the conditio sine qua non for a normal drainage of venous blood through the jugular vein.

Proliferative endophlebitis was described by Ceelen, Levin and Bucy, and Martin and Tull on the basis of biopsies. These authors 
agree that proliferative endophlebitis decreases the diameter of the lumen considerably and therefore must interfere with the return of the venous blood. Ceelen called this stenosing type of phlebitis " phlebitis productiva angustans" to express the considerable narrowing (angustation) of the lumen. He stressed the fact that the proliferation of the venous endothelium-and not the formation of thrombi-interferes with the venous return. The coarctation of the lumen which narrows it to a large degree is caused by the inflammatory changes in the endothelium.

Greifenstein, Fraenkel, and Waldapfel have stressed the excessive swelling of the endothelium in jugular veins. Waldapfel stressed this factor by illustrating his paper with an illustration showing by comparison the thickness of a normal jugular vein and the enormously increased thickness of an inflamed vein under the same magnification. Kaufmann, according to Greifenstein, found the thickening of a wall of an inflamed vein sometimes ten times as thick as the normal vein.

Any blockage of a proximal vein interferes with the drainage of all distal veins. This fact was proven experimentally by von Kries, MacMaster and Hudack.

Phlebostenosis in proximal veins increases the intravenous pressure in all distal veins. The result is a diminution of the slope in pressure and therefore an interference with the venous return.

Seidel, on the basis of tonometric and manometric experiments, proved that the pressure in the anterior chamber of the eye is considerably higher than the pressure in the episcleral voins which drain the veins of Schlemm's canal. He found in rabbits a normal intra-ocular pressure of $25-28 \mathrm{~mm}$. $\mathrm{Hg}$, while the pressure in the episcleral veins was only $7-11 \mathrm{~mm}$. $\mathrm{Hg}$.

Duke-Elder in a paper on the venous pressure and its relation to the intra-ocular pressure, found that the pressure in the veins immediately at the exit from the sclera was considerably lower than the intra-ocular pressure. The difference was about $7 \cdot 2 \mathrm{~mm}$. $\mathrm{Hg}$.

The difference in the higher pressure of the anterior chamber and the lower pressure in the episcleral veins is the deciding factor for the normal drainage of the aqueous humour through the veins of Schlemm's canal.

The smallest veins in Schlemm's canal result from a fusion of a variable number of capillaries.

Hiroishi proved experimentally the direct relation between the venous system and intra-ocular pressure $\mathrm{He}$ withdrew a certain amount of the transparent aqueous humour and replaced it with exactly the same amount of an isotonic suspension of very fine 
dyestuff particles that would enable him to observe the appearance of this dyestuff suspension in Schlemm's canal and the episcleral veins. In order not to stain the inner lining of the veins he used a non-diffusible dyestuff. He observed that this dyestuff would appear in Schlemm's canal and in the episcleral veins when the pressure in the anterior chamber was 20 to $25 \mathrm{~mm}$. $\mathrm{Hg}$. He further observed that pressure on the jugular vein stopped the drainage of the dyestuff suspension from the anterior chamber completely. He came to the conclusion that congestion in the episcleral and vortex veins would lead to a considerable increase of the venous pressure in the episcleral veins and in the veins of Schlemm's canal.

Schoenberg constructed a special cuff for the compression of the jugular veins of his patients and came to the conclusion : "One thing is certain: "the intra-ocular pressure is altered under the influence of compression of the jugulars '."

Loeal chronic inflammation of the veins of Schlemm's canal and of the vortex veins has been described by Birnbacher and Czermak. They described proliferative endophlebitis which narrows the lumen and interferes with the return of the venous blood. The question if these changes are due to augmented venous pressure or to allergic inflammation in a congested tissue does not enter our discussion.

Max Kinis also described inflammatery changes in Schlemm's canal and came to the conclusion that the main disturbance is to be found in the changed outflow of venous blood.

Besides changes in the slope of pressure the accumulation of $\mathrm{CO}_{2}$ in blood vessels with venous congestion increases the viscosity of the blood and interferes with the normal flow of blood, especially in the capillaries.

The hereditary factor plays a great rôle in glaucoma, and it may be that this factor is often important for the pathogenesis of glaucoma. Circulatory disturbances affect primarily an organ that is weak due to hereditary factors. An example is arthritis. In arthritis we find in nearly all cases inflammatory phlebostenosis in the proximal veins which is responsible for circulatory disturbances and functional changes, and, in the later stages, for structural changes of a joint.

Since Graefe in 1855 recognised the increased intra-ocular pressure in glaucoma, all efforts were directed to local pathology in the eye. Regional pathology did not enter glaucoma 'research at all. This type of pathology was neglected especially in disturbances within the head region. In a paper on the syndrome of latent jugular phlebitis Meyer, in 1937, called attention to the importance of venous congestion in the head area due to impairment of the venous return in the coarctated jugular veins. 
From a therapeutic point of view it is important to know the starting point for jugular vein infections. Fraenkel, Siegmund, and Colby Hall described pathologically the spreading mechanism of acute tonsillogenic, dentogenic, and pharyngogenic infections via the small connective veins into the jugular veins per continuitatem. It is obvious that chronic oral infections must have the same spreading mechanism. Lately the fact of bacterial phlebotropism has been stressed by Meyer in order to express an affinity of bacteria for the endothelium of the veins.

The starting point in oral focal infections is nearly always an infection in the small tonsillar veins and a thrombophlebitis in the small veins of the dental pulp.

Siegmund and Roessle found pathological changes in the small tonsillar veins, while Wassmund and Bingold stress the importance of thrombophlebitis in the pulp as the starting point of dental focal infection.

Experimental proof of this important factor should be easy. Hueper was able to produce experimental jugular phlebitis in dogs by infecting the pulp canal with streptococci. Since the dental pulp according to Bremer has no lymphatic vessels, it is obvious that pulp infections can only spread by way of the small pulp veins.

It is imperative to eradicate primary oral foci completely in order to avoid a reinfection of the jugular veins from these sources. Root fragments and tonsillar stumps are especially dangerous, as they lack drainage to the mouth cavity.

I described the frequency, the danger, and the diagnosis of infected tonsil remnants lately in a paper on the incidence and significance of tonsil remnants.

After complete removal of the primary oral foci, the jugular endophlebitis persists in nearly all cases as an independent infection. The treatment of jugular phlebitis with leeches is empirical and was applied by Meyer after he had such excellent results with leeches in the treatment of purulent phlebitis in the lower extremities.

Leeches were used by ophthalmologists for a long time in glaucoma cases. But all of them applied leeches over the temple region in glaucoma patients. This application could result only in a local temporary decongestion of the eye.

Recalibration of the jugular veins with leeches, on the other hand, brings on a total decongestion of the whole'head area, and therefore has a permanent therapeutic effect.

\section{Summary}

Glaucoma exogenicum has its cause outside of the eye in chronic proliferative endophlebitis of the jugular veins. 
Jugular endophlebitis has a narrowing effect on the vein lumen which interferes with venous drainage of the head region.

Blockage of the proximal jugular vein produces an increase in venous pressure in all distal veins, including the episcleral veins which drain the veins of Schlemm's canal.

The deciding factor for a normal drainage of the aqueous humour from the anterior chamber is the difference of the higher pressure in the anterior chamber and the lower pressure in the veins of Schlemm's canal and the episcleral veins. If the venous pressure of the veins in Schlemm's canal and the episcleral veins equals or exceeds the intra-ocular pressure, the slope in pressure is eliminated, and the drainage of the anterior chamber is stopped completely.

The treatment of exogenic glaucoma resolves itself into a recalibration of the jugular veins.

\section{REFERENCES}

BIRNBACHER UND CzERMAK.-Beitrage zur pathologischen Anatomie des Glaukoms. Graefe's Arch., Vol. XXXI, p. 297, Vol. XXXII, pp. 1-4. 1885.1886.

BINGOLD, KonRAD.-Die septischen Erkrankungen. Urban \& Schwarzenberg, Berlin und Wien. 1937.

BREMER, WEATHERFORD.-Textbook of Histology. Blakiston. 1944.

CEelen, W.-Ueber Extremitaetenbrand. Arch.f. klin. Chir., Vol. CLXXIII, p. 742. 1932.

DUKE-ELDER, STEWART, W. - The venous pressure of the eye and its relation to the intra-ocular pressure. Jl. of Physiol., Vol. LXI, p. 409.1926.

Fraenkel, E.-Ueber postanginoese Pyaemie. Deutsche med. Wochenschr., Vol. LII, p. 93. Jan. 15, 1926.

GREIFENSTEIN, A.-Pathologisch-anatomische Untersuchung thrombotisch entzundlicher Vorgaenge im Halsvenensystem. Virchow's Arch., p. 281. 1931.

Hall, Colby.-Sepsis following pharyngeal infections. Ann. Otol. Rhin. and Laryng., Vol. XLVIII, pp. 905-925. Dec., 1939.

HiROISHI - Ueber das Verhaeltnis zwischen Augendruck und Blutdruck in den episcleralen Venen und den Wirbelvenen. Arch.f. Ophthal., Vol. CXIII, p. 212.1924.

Hueper, W. C.-Experimental jugular phlebitis. Amer. Jl. Clin. Path. March, 1946.

KAUFMANN.-quoted by Greifenstein.

KINIS, MAX.- Ueber das Glaukom: Graefe's Arch., Vol. XXXIII/2, p. 62. 1887.

KRIES, von.- Ueber den Druck in den Blutkapillaren der menschlicben Haut.

Verhandl. der Koenigl, Saechs. Ges. der Wiss., Bd., Vol. XXVII, pp. 149-155. 1875.

LEVIN and Bucy.--Proliferative Endophlebitis (phlebosclerosis). Arch.f. Int. Med., Vol. LVII, p. 787. April, 1936.

MARTIN, C. F., and TULL, J. A C.-Peripheral phlebosclerosis in childhood. Arch.f. Ped., Vol. XXV, pp. 191-194. 1908.

MCMASTER and HUDACK. - The vessels involved in hydrostatic transudation. $J l$. f. Exp. Med., Vol. LV, pp. 417-429. March 1., 1932.

MEYer, OTTO.-Die latente chronische Entzundung der Jugularvenen. Zentralbl. f. Innere Med., No. 37. 1937.

Spaetschaeden nach Erfrierungen. Zur Aetiologie der Endangiitis obliterans. Schweiz. Med. Wchnschr., No. 18. May 1, 1943.

The primary cause of glaucoma. The Eye, Ear, Nose and Throat Monthly. Vol. XXIV, pp. 586-593. Dec., 1945. 
MEYER, OTTO.-Entzundliche Jugularstenose als Ursache des primaeren Glaukoms. Schweiz. Med. Wchnschr. May 11, 1946.

-Incidence and significance of infected tonsil remnants. The Eye, Ear, Nose and Throat Monthly, Vol. XXV, pp. 244-246. May, 1946.

Roessle.-Ueber Fokalinfektion. Verh. d. deutsch. Gesellsch. f. Innere Med., Vol. LI, p. 423. 1939.

SCHOENBERG, M. J.-Remarks on artificial induction of ocular hypertension by compression of the jugular veins. Arch. Ophthal., Vol. I, pp. 681-691. June, 1929.

SEIDEL.-Experimentelle Untersuchungen ueber intraokulaere Saftstoerung : IX. Ueber den Abfluss des Kammerwassers. Arch. f. Ophthal., Vol. CIV, p. 357. 1921.

-Ueber den manometrischen Nachweis des physiologischen Druckgefaelles zwischen Vorderkammer und Schlemmschen Kanal. Graefe's Arch., Vol. CVII, p. 101 . 1921-1922.

Siegmund, H.- - Ueber die akute Phlebitis der Halsvenen bei odontogenen Kiefererkrankungen als Ausgang septischer Allgemein-Infektionen. Deitsche Zahn-, Mund-, u. Kieferheilk., Vol. LXXIV, pp. 56-61. 1929.

- Pathologish-anatomische Befunde an dentalen Kieferherden bei pulpenlosen Zaehnen mit Bemerkungen zur Frage der chronischen Tonsillitis. Verhandl. d. Deutsch. Gesellsch. f. Innere Med., Vol. LI, p. 544. 1939.

WALDAPFEL. - Zur Klinik und Therapie der Sepsis nach Angina. Wien. Klin. Wochnschr., Vol. XLVIII, p. 136. Feb. 1, 1935.

WASSMUND, M.-Ueber fokale Infektion. Zentralbl. f. Chir., Vol. LXII, p. 2161, 1935.

\title{
OCULAR LESIONS IN INTERNEES AT A CIVILIAN INTERNMENT CAMP AT HONG KONG*
}

\author{
BY \\ H. TALBOT \\ HONG KONG
}

Amongst the inmates at a Civilian Internment Camp at Stanley, Hong Kong, a number of ocular symptoms were observed during the Japanese occupation. The general conditions prevailing in the camp were none too good. Food was not plentiful; there were only two meals a day. After about the first year in camp meat was not included in the dietary, except on three or four occasions. Towards the last month of internment water-buffalo (? horse) was supplied. Fish, usually as fresh raw fish, or as dried-salted, was not frequently given, and when 'supplied it was always in small quantities.

During the three and three-quarter years' internment everybody received four Red Cross parcels; a number of internees, perhaps 40 per cent. in the early days dwindling to 10 per cent. or less later on, received parcels of food from friends (Chinese and third Nationals) living in Hong Kong. In the early days it was possible to augment the rations with food bought at the canteen,

\footnotetext{
* Received for publication, June 13, 1946.
} 